\title{
Initial spread of the invasive green alga Caulerpa verticillata over coral reef communities in the Gulf of California
}
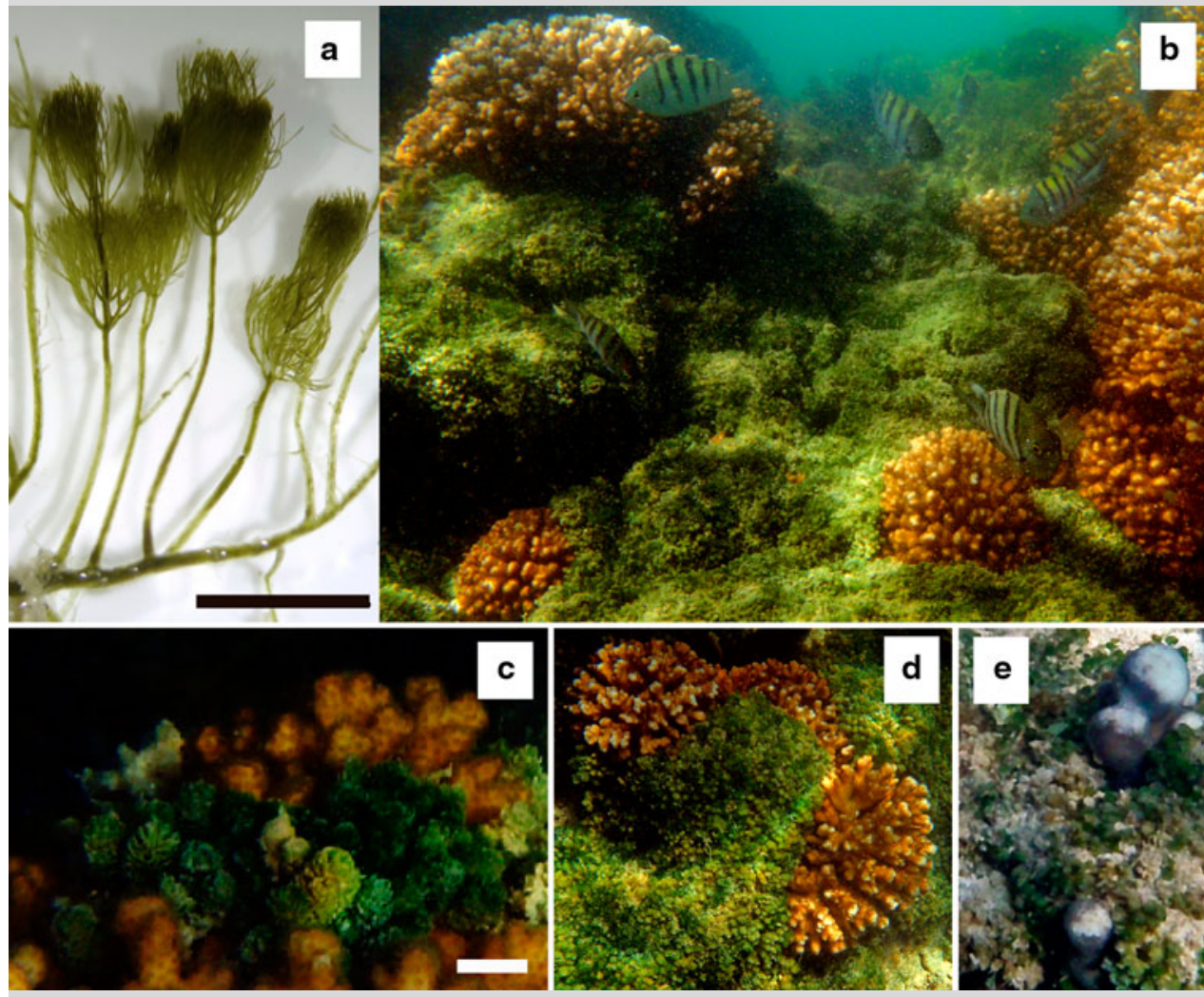

Fig. 1 a Alga Caulerpa verticillata $\mathbf{b}$ C. verticillata growing over coral reef community c Detail of algal growth bet
d, e Alga overgrowing colonies of Pocillopora damicornis and Porites panamensis, respectively. Scale bars $1 \mathrm{~cm}$

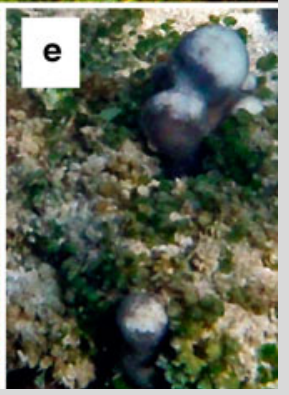

tween branches of Pocillopora damicornis (Fig. 1c) and over P. damicornis and Porites panamensis colonies (Fig. $1 \mathrm{~d}$,e). Surveys of 12 sites (from $24.04^{\circ} \mathrm{N}$ to $24.74^{\circ} \mathrm{N}$ ) between 2010 and 2012 indicated that $C$. verticillata so far remains limited to the three sites above. This is the first report of $C$. verticillata overgrowing coral reef communities in the Gulf of California. This finding emphasizes that regular reef monitoring will be necessary to evaluate the effects of this algal invasion on coral populations in this region.

Acknowledgments We thank J. Zarate-Rustrian and F. López-Rasgado for field assistance, J. Díaz-Sánchez for ArcGIS calculations. We appreciate the comments of E. Serviere-Zaragoza and the editorial services of I. Fogel.

References

Fernández C, Cortés J (2005) Caulerpa sertularioides, a green alga spreading aggressively over coral reef communities in Culebra Bay, North Pacific of Costa Rica. Coral Reefs $24: 10$

Kružić P, Žuljević A, Nikolić V (2008) The highly invasive alga Caulerpa racemosa var. cylindracea poses a new threat to the banks of the coral Cladocora caespitosa in the Adriatic Sea. Coral Reefs 27:441

Lapointe BE, Bedford BJ (2010) Ecology and nutrition of invasive Caulerpa brachypusf. parvifolia blooms on coral reefs of southeast Florida, U.S.A. Harmful Algae 9:1-12 Mateo-Cid LE, Mendoza-González AC (1991) Algas marinas bénticas de la costa del estado de Colima, México. Acta Botánica Mexicana 13:9-30

Pérez-Justavino L, González-Otero A, Martínez I, Ríos R, Tejada O, Villareal R (2010) Macroalgas de Playa Hermosa, Costa Pacífica de Chiriquí, Panamá. Puente Biológico 3:127-143

C. J. Pérez-Estrada $(\bowtie) \cdot$ R. Rodríguez-Estrella $\cdot$ D. A. Paz-García

Centro de Investigaciones Biológicas del Noroeste, S.C., Instituto Politécnico Nacional 195, Col. Playa Palo de Santa Rita Sur, 23096 La Paz, B.C.S., Mexico e-mail: claudiap@cibnor.mx

D. S. Palacios-Salgado

Escuela Nacional de Ingeniería Pesquera, (ENIP-UAN), Apto. Postal 10, 63740 San Blas, Nayarit, Mexico

Received: 10 January 2013/Accepted: 11 May 2013/Published online: 25 May 2013

Coral Reefs (2013) 32:865

(C) Springer-Verlag Berlin Heidelberg 2013

DOI 10.1007/s00338-013-1045-x 